\title{
Cutaneous Sarcoidosis Associated with Vitiligo and Autoimmune Thyroiditis - a Case Report
}

\author{
Jovan LALOŠEVIĆ ${ }^{1}$, Dušan ŠKILJEVIĆ ${ }^{*}$ \\ ${ }^{1}$ Clinic of Dermatovenereology, Clinical Center of Serbia \\ ${ }^{2}$ Clinic of Dermatovenereology, Clinical Center of Serbia; Department of Dermatovenereology, \\ School of Medicine, University of Belgrade
}

${ }^{*}$ Correspondence: Dušan Škiljević, E-mail: dusanskiljevic@yahoo.com

UDC 616.5-002.7:616.441-002]-097

616.5-002.7-097:616.5-003.829

\section{DE GRUYTER OPEN}

\begin{abstract}
Sarcoidosis is a multisystem granulomatous disease and approximately one third of patients with the systemic form develop skin lesions. We present a case of cutaneous sarcoidosis associated with autoimmune thyroiditis and vitiligo. Although this association is rare by itself, it imposes the theory of autoimmune etiology of sarcoidosis. Moreover, our patient presented with elevated levels of serum chitotriosidase, a known biomarker in the activity of systemic sarcoidosis. To the best of our knowledge, there are no reports of chitotriosidase in isolated cutaneous sarcoidosis, raising a possible field for future research.
\end{abstract}

\section{Key words}

Sarcoidosis; Skin Diseases; Thyroiditis, Autoimmune; Vitiligo; Comorbidity; Hexosaminidases

Sarcoidosis is a multisystem granulomatous disease characterized by hyperactivity of the cell-mediated immune system. Cutaneous sarcoidosis can be isolated, or it can be a part of a systemic sarcoidosis (approximately one third of all patients with systemic form develop cutaneous sarcoidosis) (1).

\section{Case report}

We present a case of a 53-year-old woman with autoimmune thyroiditis and vitiligo (stable in the past 4 and 10 years, respectively), involving 20\% body surface, who developed multiple, asymptomatic, erythematous papules and nodules over the sunexposed areas (nose, lateral sides of her arms, elbows, shins and dorsal feet) in the year preceding the examination (Figures 1, 2, 3). Some of these lesions were localized on areas affected by vitiligo, especially on the elbows and dorsal feet (Figures 2,3).

A skin biopsy of a papule on the elbow and histopathological analysis revealed non-caseating, well-defined, naked granulomas in the dermis consistent with sarcoidosis (Figure 4). Mycological and mycobacterial cultures of skin biopsies were negative. A chest X-ray did not reveal any signs of hilar lymphadenopathy or interstitial infiltrate. Also, serum levels of angiotensin-converting enzyme (ACE) were normal, and there was no increase in 24 hour calciuria.

Laboratory tests showed elevated erythrocyte sedimentation rate $(30 \mathrm{~mm} / \mathrm{h})$, slightly lower levels of hemoglobin - $115.9 \mathrm{~g} / \mathrm{L}$ (reference values 122$155 \mathrm{~g} / \mathrm{L}$ ), whereas the rest of laboratory findings were within normal ranges - complete blood count with differential, urinalysis, lipid status, renal and liver biochemistry, serum levels of amylase, lipase, lactate dehydrogenase; tumor markers - carcinoembryonic antigens (CEA), alphafetoprotein antigens (AFP), carbohydrate antigen (CA 19-9). The thyroid function test showed elevated levels of thyreo-stimulating hormone - $7.32 \mathrm{mIU} / \mathrm{L}$, anti- thyroglobulin (Tg) 


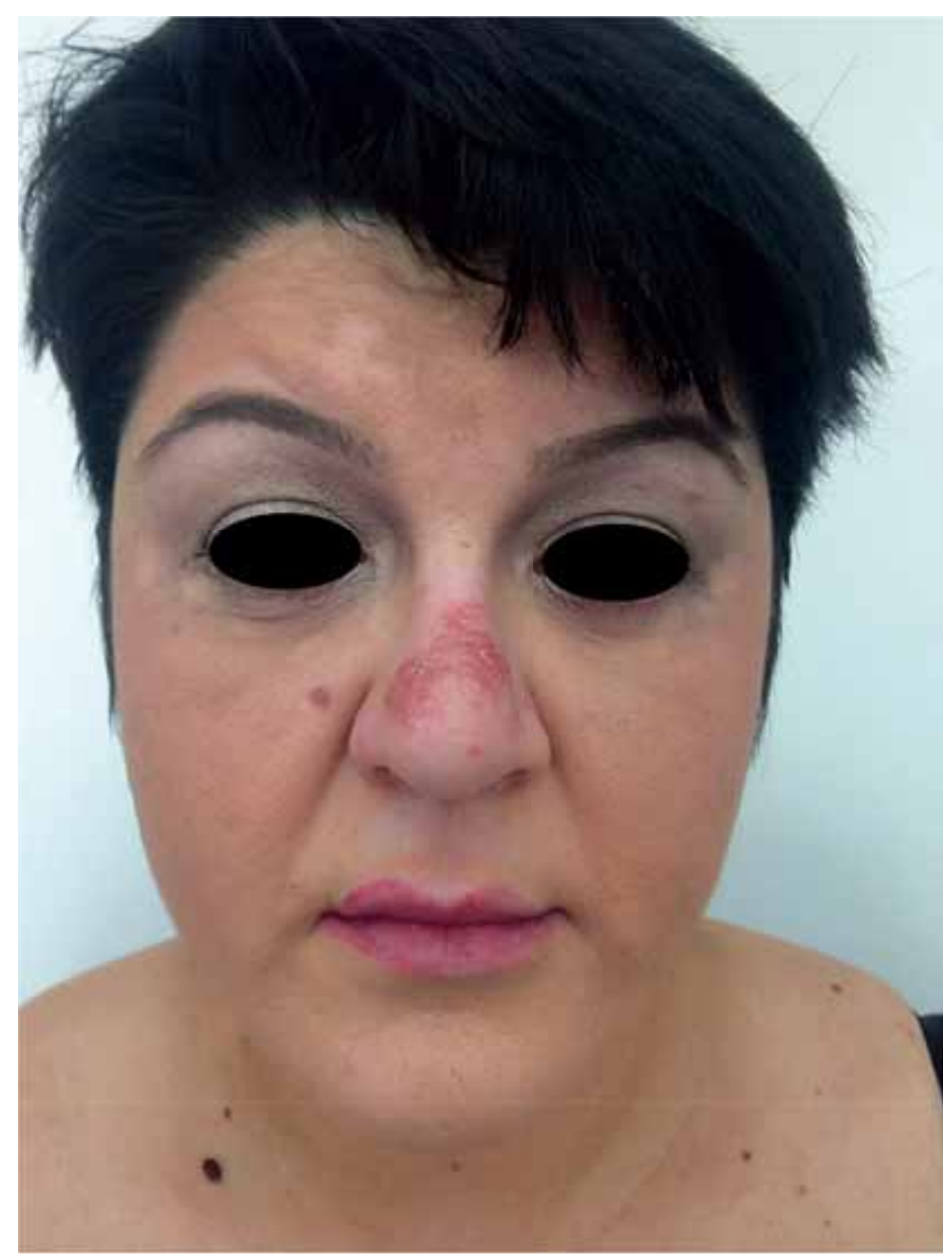

Figure 1. Confluent erythematous papules on the patient's nose

antibodies - $350.83 \mathrm{IU} / \mathrm{mL}$, and anti- thyroperoxidase (TPO) antibodies - $517.24 \mathrm{IU} / \mathrm{mL}$, verifing the diagnosis of chronic autoimmune thyroiditis. Also, elevated levels of serum chitotriosidase $-180 \mathrm{nmol} /$ $\mathrm{mL} / \mathrm{h}$ (normally $1.80-146.6 \mathrm{nmol} / \mathrm{mL} / \mathrm{h}$ ) was noted. Antinuclear antibodies, of a homogenous type, were present in the patient's serum at a titer of 1:40. ENA screen was within reference values, while anti-dsDNA antibodies and rheumatoid factor were negative.

\section{Discussion}

An association of sarcoidosis with autoimmune diseases has been recognized in the past, especially with lupus erythematodes (2) and autoimmune thyroiditis (3). Nevertheless, there are few reports of patients with sarcoidosis, autoimmune thyroiditis and vitiligo $(4,5,6)$.

The exact etiopathogenesis of sarcoidosis is still not elucidated, even though it is widely accepted that an unrecognized antigen is responsible for the cascade of non-caseating granuloma formation. This hypothesis would be confirmed by the development of characteristic skin granulomas after injecting KveimSiltzbach's antigen (sarcoid tissue prepared from the spleen) (7).

Both vitiligo and autoimmune thyroiditis are considered to be a result of self-intolerance, with the development of autoantibodies against thyreocytes and melanocytes $(8,9)$. In cases of cluster autoimmunity, as in our patient, the bigger issue is if this hyperreactivity 


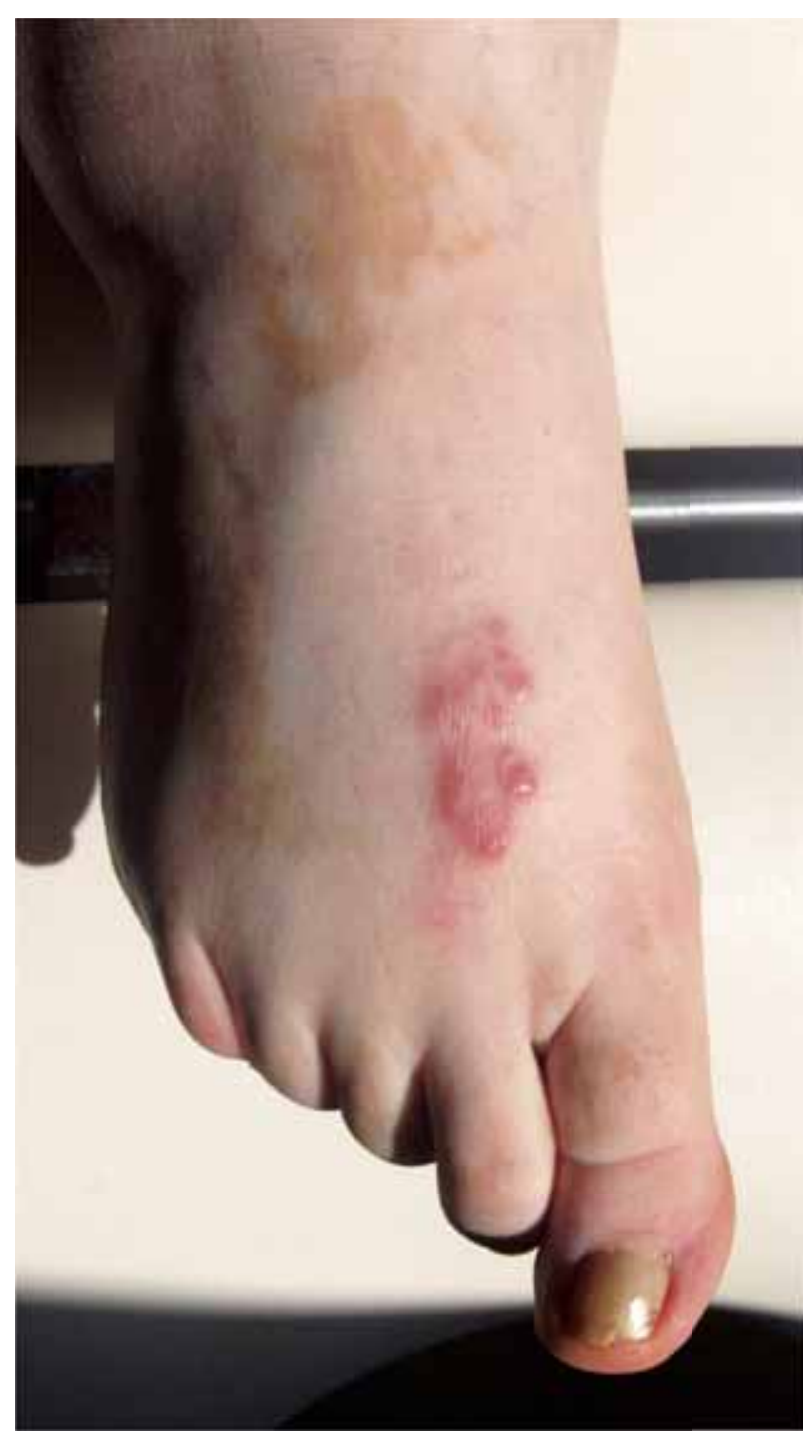

Figure 2. Erythematous papules and small nodules on vitiligo macules

leads to the development of immunological response to a still undefined antigenic stimulus (10). Another question is the nature and origin of the presumptive antigen: is it from the environment, continuously present, or perhaps antigen preexisting in the organism but not recognized by the immune system.

In cases of vitiligo associated with sarcoidosis reported in the literature, sarcoidal lesions sporadically appear on vitiligo macules. This was also the case in our patient. Some authors postulate that photodamage within the vitiliginous skin may alter the expression of antigens identified by T-cell, such as the case of lichen planus and psoriasis confined to vitiligo lesions (11,

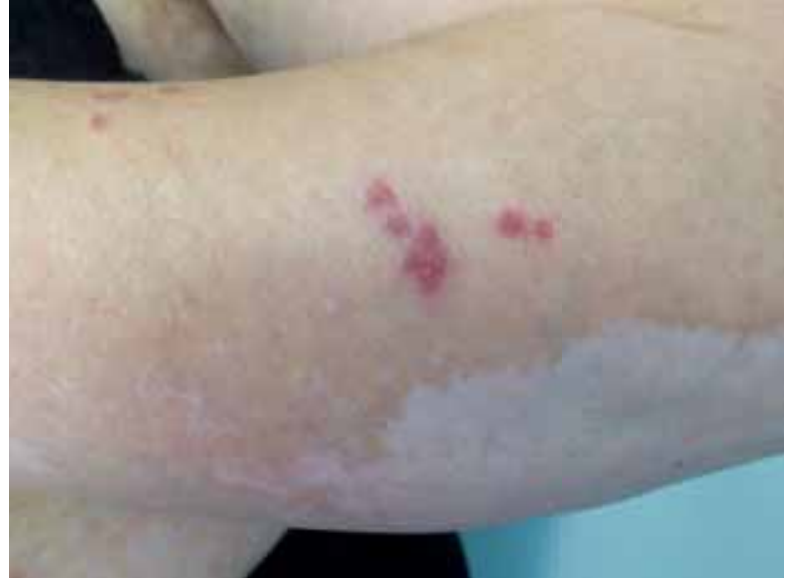

Figure 3. Erythematous papules and small nodules on unaffected skin

12). Julian et al. proposed that some kind of cellular injury in vitiliginous skin might lead to an immune mechanism causing Koebner's phenomenon (13).

Taking into consideration that our patient had autoimmune thyroiditis and vitiligo, we believe that she should be monitored for diabetes mellitus, since by some authors sarcoidosis can be related to various polyglandular autoimmune syndromes $(6,14,15)$.

Human chitotriosidase (HC) has proven to be a biomarker with high sensitivity and specificity in the detection of systemic sarcoidosis $(16,17)$. Sensitivity is estimated to about $90 \%$, which exceeds the sensitivity of commonly used biomarker ACE of about $60 \%$ $(18,19)$. Even though our patient did not have $x$-ray findings consistent with pulmonary sarcoidosis, she

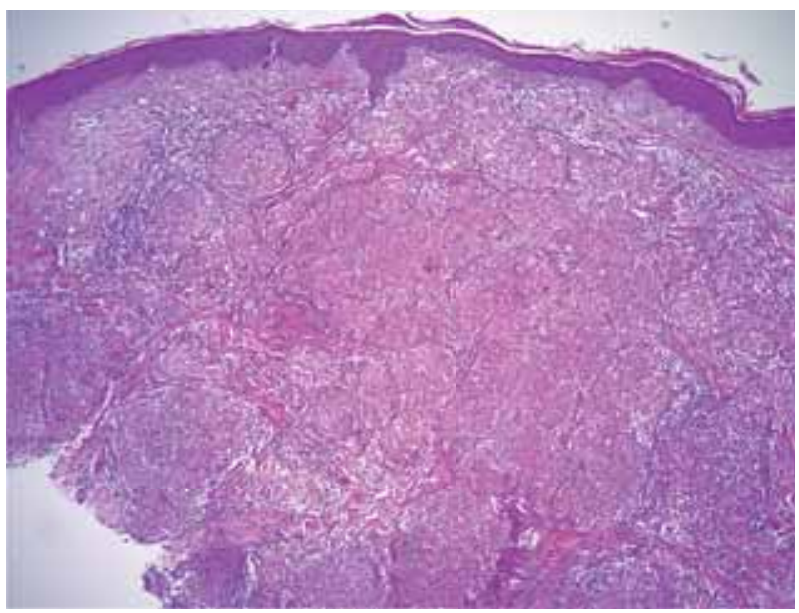

Figure 4. Non-caseating, well-defined, naked granulomas in the dermis (Hematoxylin-Eosin, $\mathrm{x} 40$ ) 
presented with elevated levels of serum HC. In the available literature, there is no evidence about the activity of $\mathrm{HC}$ in cutaneous sarcoidosis. We believe that further investigations are required to reveal if levels of serum $\mathrm{HC}$ in cutaneous sarcoidosis may be a prognostic factor in the development of systemic sarcoidosis, or a good biomarker of isolated cutaneous sarcoidosis.

\section{Conclusion}

In conclusion, we present a case with a rare clustering of autoimmune diseases: autoimmune thyroiditis, vitiligo and cutaneous sarcoidosis. To date, there have been no reports of isolated cutaneous sarcoidosis with such clustering. Moreover, elevated HC serum levels may implicate that our patient's sarcoidosis may progress to a pulmonary disease. This hypothesis, however, needs to be explored in further investigations.

\section{Abbreviations}

ACE - angiotensin-converting enzyme

CEA - carcinoembryonic antigen

AFP - alphafetoprotein antigens

CA - carbohydrate antigen

$\mathrm{Tg}$ - thyroglobulin

TPO - thyroperoxidase

ENA- extractable nuclear antigens

anti-dsDN - anti-double-stranded

desoxyribonucleic acid

HC - human chitotriosidase

\section{References}

1. Howard A, White CR Jr. Non-infectious granulomas (sarcoidosis). In: Bologna J, Jorizzo J, Rapini R, editors. Dermatolgy. 2nd ed. London-Edinburgh-New York-Philadephia-St Louis-SydneyToronto: Mosby; 2003. p. 1455-60.

2. Wesemann DR, Costenbader KH, Coblyn JS. Coexisting sarcoidosis, systemic lupus erythematosus and the antiphospholipid antibody syndrome: case reports and discussion from the Brigham and Women's Hospital Lupus Center. Lupus 2009;18:202-5.
3. Isern V, Lora-Tamayo J, Capdevila O, Villabona C, Mañá J. Sarcoidosis and autoimmune thyroid disease. A case series of ten patients. Sarcoidosis Vasc Diffuse Lung Dis 2007;24:148-52.

4. Terunuma A, Watabe A, Kato T, Tagami H. Coexistence of vitiligo and sarcoidosis in a patient with circulating autoantibodies. Int J Dermatol 2000;39:551-3.

5. Demirkök SS, Arzuhal N, Devranoğlu G, Demirkesen C, Tüzün Y. Recurrent sarcoidosis on a scar associated with vitiligo. J Dermatol 2007;34:829-33.

6. Papadopoulos KI, Hallengren B. Polyglandular autoimmune syndrome type III associated with coeliac disease and sarcoidosis. Postgrad Med J 1993;69:72-5.

7. Kataria YP, Holter JF. Immunology of sarcoidosis. Clin Chest Med 1997;18:719-39.

8. Passeron T, Ortonne JP. Physiopathology and genetics of vitiligo. J Autoimmun 2005;25 Suppl:63-8.

9. Weetman AP. The immunopathogenesis of chronic autoimmune thyro-iditis one century after hashimoto. Eur Thyroid J 2013; 1:243-50.

10. Tchernev G, Ananiev J, Cardoso JC, Wollina U, Verma SB, Patterson JW, et al. Sarcoidosis and molecular mimicry-important etiopathogenetic aspects: current state and future directions. Wien Klin Wochenschr 2012;124:227-38.

11. Anstey A, Marks R. Colocalization of lichen planus and vitiligo. Br J Dermatol 1993;128:103-4.

12. Sardana K, Sharma RC, Koranne RV, Mahajan S. An interesting case of colocalization of segmental lichen planus and vitiligo in a 14-year-old boy. Int J Dermatol 2002;41:508-9.

13. Julian CG, Bowers PW. Strict anatomical coexistence of vitiligo and psoriasis vulgaris--a Koebner phenomenon? Clin Exp Dermatol 1996;21:464.

14. Karlish AJ, MacGregor GA. Sarcoidosis, thyroiditis, and Addison's disease. Lancet 1970;2(7668):330-3.

15. Seinfeld ED, Sharma OP. TASS syndrome: unusual association of thyroiditis, Addison's disease, Sjögren's syndrome and sarcoidosis. J R Soc Med 1983;76:883-5.

16. Bargagli E, Bennett D, Maggiorelli C, Di Sipio P, Margollicci M, Bianchi N, et al. Human chitotriosidase: a sensitive biomarker of sarcoidosis. J Clin Immunol 2013;33:264-70.

17. Boot RG, Hollak CE, Verhoek M, Alberts C, Jonkers RE, Aerts JM. Plasma chitotriosidase and CCL18 as surrogate markers for granulomatous macrophages in sarcoidosis. Clin Chim Acta 2010; 411:31-6.

18. Sharma OP. Markers of sarcoidosis activity. Chest 1986;90:471-3.

19. Harlander M, Salobir B, Zupančič M, Dolenšek M, Bavčar Vodovnik T, Terčelj M. Serial chitotriosidase measurements in sarcoidosis--two to five year follow-up study. Respir Med 2014; 108:775-82. 


\section{Kutana sarkoidoza udružena s vitiligom i autoimunim tiroiditisom - prikaz slučaja}

\section{Sažetak}

Sarkoidoza predstavlja multisistemsko granulomatozno oboljenje u kome je zahvaćena i koža kod trećine pacijenata. Naš prikaz je pacijent sa kutanom formom sarkoidoze udruženom sa autoimunim tiroiditisom i vitiligom. Ova asocijacija (povezanost ili komorbiditet) sam po sebi je redak i implicira na autoimunu etiologiju sarkoidoze. Naš pacijent je imao i povišene nivoe serumske hitotriozidaze, prepoznatog biomarkera aktivnosti sarkoidoze. Pretaživanjem literature nismo došli do podataka o nivoima serumske hitotriozidaze kod izolovane kutane sarkoidoze, otvarajući potencijalne sfere daljeg naučnog istraživanja.

\section{Ključne reči}

Sarkoidoza; Kožne bolesti; Autoimuni tiroiditis; Vitiligo; Komorbiditet; Heksosaminidaze 